\begin{tabular}{c} 
Volume and Issues Obtainable at Center for Sustainability Research and Consultancy \\
Journal of Business and Social Review in Emerging Economies \\
ISSN: 2519-089X (E): 2519-0326 \\
Volume 6: Issue 2, June 2020 \\
JSR \\
Journal homepage: www.publishing.globalcsrc.org/jbsee \\
\hline
\end{tabular}

\title{
Assessment of Professional Learning Community in Private Schools of Lahore
}

\author{
${ }^{1}$ Sajid Masood, ${ }^{2}$ Ghazal Khalid Siddiqui, ${ }^{3}$ Huma Lodhi, \\ ${ }^{1}$ Assistant Professor, University of Management \& Technology, Lahore, Pakistan, sajid @umt.edu.pk \\ ${ }^{2 \& 3}$ Assistant Professor University of Education Lahore, Pakistan, ghazalkhalid@ue.edu.pk, \\ huma.lodhi@gmail.com
}

\begin{tabular}{l}
\hline ARTICLE DETAILS \\
\hline History \\
Revised format: May 2020 \\
Available Online: June 2020 \\
\\
\hline Keywords \\
Professional Learning, Shred \\
and Supportive Leadership,, \\
Collaboration, Vision and \\
Values, Community \\
\hline
\end{tabular}

JEL Classification

MO, M5

\begin{abstract}
The purpose of the study was to investigate existence of professional learning community (PLC) in five private schools of Lahore. The researcher used an instrument Professional Learning Community Assessment Revised developed and revised by Olivier, Hipp, and Huffman (2010) to collect data from 800 teachers from five private reputed schools of the Lahore. The sample was selected conveniently because of very limited to no access to certain schools. With response rate of $80 \%$ and reliability of .951 in local context the data were analyzed. The analysis revealed existence of all dimensions of PLC in all five schools of the Lahore. Supportive condition (structure) was perceived as dominant dimension of the PLC. Insignificant difference was identified between perceptions of male and female teachers. Moreover ANOVA revealed that in Heaven school and Custodian school two dimensions of the PLC, shared and supportive leadership and shared values and vision are practiced better than other three schools: Shining star, Grammar, and Hospitality. This research has identified existence of PLC in private schools of the Lahore and invites researchers to explore the same in public schools and further investigate relationship of PLC with school effectiveness, students' achievement, teachers" professional development and other variables.
\end{abstract}

\section{OPEN ACCESS}

(C) 2020 The authors, under a Creative Commons AttributionNonCommercial 4.0

Corresponding author's email address: sajid@umt.edu.pk

Recommended citation: Masood, S., Siddiqui G. K., Lodhi, H., Ali, H. (2020). Assessment of Professional Learning Community in Private Schools of Lahore. Journal of Business and Social Review in Emerging Economies, 6(2), 619-628

\section{Introduction}

Schools always remained focus of various actors including statesmen, policy makers, philosophers, educationists and many more. Its role in upbringing of future citizenship remains under scrutiny and its effectiveness concerned both internal and external stakeholders. From Coleman report to school effectiveness movement and No Child Left Behind (NCLB) legislation, efforts were being made to identify and strengthen processes which directly or indirectly impact students' achievements. These 
reforms and developments triggered the need to further improve not only teaching learning process but to address those allied resources and milieu which are directly or indirectly impacting the teaching learning process. One of such processes which is very critical for the improvement of not only teaching learning process, but overall professional wellbeing of the teachers is PLC. PLC was initially considered as a revolt against the reforms imposed from outside and teacher' isolation in schools. It is being associated with decreased teachers' isolation and increased collaboration to improve students, learning (DuFour \& Eaker, 1998). PLC is considered to be a setting in schools where teachers and principals work in a collaborative way to improve not only their practices but achievements of their students as well (Hord 1997). DuFour and Eakter (1998) equated the PLC with a movement or reform to address teachers' isolation and status quo by creating an environment which fosters collaboration, sharing of experiences, professional dialogue, support and teamwork. DuFour (2007) further reiterated that PLC is effective strategies for improving and sustaining student achievement. It creates communities of individuals with common interests and transforms them to better serve the purposes of the institutions (DuFour, DuFour, \& Eaker, 2006; Napier \& Gershenfeld, 2001). PLC has several dimensions which were empirically identified by a number of researchers (Hord \& Sommers, 2008; Blankstein, 2010; Oliver, Hipp \& Huffman, 2010; DuFour, et.al, 1998). A brief descriptions of dimensions of PLC are presented to give readers a background of the construct.

\subsection{Supportive and Shared Leadership}

More than five decades of research is consistently identifying importance of leadership particularly that style of school leadership which is making a difference at workplace like distributed leadership, servant leadership, balanced leadership, organizational leadership and as professional developer. Therefore, a leadership which is supportive, sharing responsibilities and nurturing professional self of the teachers is an antecedent for developing and sustaining PLC (Prestine, 1993; Louis and Kruse, 1995; Fullan and Stieglebauer, 1991). The authority for leadership resides in sharing of ideas (Sergiovanni, 1994) and decision making. If principal is authoritative, staff will not propose divergent ideas for effectiveness of school and will lack commitment (DuFour, et al.,1998). The principals also need appreciation, sympathy and support in their work and professional development. Some other leadership styles of the principals like transformational and instructional leaders are also considered as critical to persuade the team to achieve goals of school through shared decision making, creating climate of high expectations and leading all with a tone of respect (Smith \& Andrews,1989; Leithwood 1994; Leithwood \& Duke,1998; Marks \& Printy,2003; Hallinger \& Heck,1996). Therefore supportive and shared leadership is a key to establish PLC in school and to make it a successful one as Leithwood \& Riehl (2003) rightly identified that excellent schools are because of excellent principals and weak leadership is making a school failure.

\subsection{Collective Learning}

Existence and sustenance of PLC demand nurturing collective learning and collaboration at workplace (Pang, Wang \& Leung, 2016) and one of achieving it build bridges than walls so that people interact in teams and decide collectively (Hilliard, 2012). Collective learning occurs in various ways like team teaching, curriculum development and mapping, peer observation, resolving students' related issues, sharing teaching techniques impacting learning of students, giving feedbacks and having an opportunity for collaborative inquiry to deal with new challenges become successful in preparing their students in terms of skills, content knowledge, behaviors and lifelong learning to compete not only locally but globally as well (Hilliard, 2012; Darling- Hammond, 1996; Little,1990; Mc Laughlin \& Talbert,1993; Hipp, Huffman, Pankake \& Oliver, 2008; Nelson, 2009; Pella, 2011; Dufour, 2004; Leiberman \& Miller, 2011). Working collectively and collaboratively not only develop teachers professionally in art and craft of teaching but help them to share and accept ideas of others after reflecting critically and at the same time becoming aware of their own learning deficiencies, thus constructing realities through sharing and feedback (Brodie, 2013; Tam, 2015). Even this culture of collective learning can trigger progress of students if teachers tailor instructional programs keeping in view students input (Tan \& Caleon, 2016). This phenomenon get set back in case the actors lack motivation, commitment and having very rigid dispositions (Malony \& Konza, 2011). 


\subsection{Shared Values and Vision}

School improvement is not possible without developing a vision (Boyer 1995; Fullan, 1997). It is not just writing a statement, but it reflects desired organizational goals indicating direction of actions to implement change. The shared vision is the base on which pillars of programs and policies are raised. Senge (1990) argued that learning organizations are characterized by creating collective vision and then pursuing it as a team. A shared vision does not let the stakeholders deviate from the purpose of student learning (Louis and Kruse, 1995; Gini Doolittle, 2008). It is an indication that a quality process is in action in an organization (Fullan, Hill \& Crevola, 2006). Shared vision and values inculcates feeling of possession and dedication in community members (DuFour, et al., 1998; Oliver, Hipp, \& Huffman, 2010).

\subsection{Shared Personal Practice}

The teachers who are eager to play their role in improvement of each individual student share their practices with peers with mutual respect and reliability (Wignall 1992). Shared personal practice creates an environment of support for innovations, risk taking, and performing tough tasks willingly (Midgley \& Wood, 1993). Professional learning is a daunting task as it demands lot of time and energy; the stress is minimized by sharing and getting feedback of colleagues (Brodie, 2013).

\subsection{Supportive Conditions}

For PLCs to work effectively, supportive relational factors comprise of collegiality and efficacy. The teachers should have sense of ownership, inclusiveness, and community in the work environment (Louis \& Kruse, 1995). Support by the leadership, networks of teachers and community gives teachers feeling of self-efficacy and they agree to adopt new classroom practices to meet the students' needs (Rosenholtz 1989; Mc Laughlin \& Talbert, 2006; Tam 2010; Wong, 2010). The "individual-organizational learning relationship" makes people feel safe, they do happily what needs to be done asserts (Wenger, 1998). Their attachment to the organization and their work is strengthened ( Leach, 2009). Management of power relationships through staffs' contribution in hiring new teachers and administrators make them more responsible in performing their own duties with feeling of ownership.( Louis \& Kruse ,1995; Dana $\&$ Yendol-Hoppey, 2008) School-based professional development programs is another way to empower teachers to optimize their capacities and sustain PLCs. Professional development during school hours can help teachers use data to reflect on their practices and change their instruction methodology at the spot.

Along with excellent human relationships the PLCs culture should also be supported with conducive physical and structural arrangements ( Boyd,1992; Louis \&Kruse, 1995; Tam, 2015) The availability of structured time for reflection, visiting other classrooms, work with students of special needs and share classroom practices with colleagues for school improvement (Darling-Hammond, 1996) is crucial for success of PLCs. Structural changes like hiring curriculum experts, mentoring and coaching, establishing committees to plan and materialize innovations engage teachers intellectually in social development and improvement of student performance. (Tam, 2010; Grossman, Wineburg \& Woolworth., 2001). Also, smaller school size to ensure proximity and effective communication are thought to be important to structural arrangements (Hord, Abrego, Moller, Oliver, Pankake, \& Rountree, 2010).

The literature has identified several dimensions of the PLC which are instrumental for the success of this newly emerged process of professional uplift of teachers and student achievement. The concept is still not explored in context of Pakistan. Although the state of education in Pakistan is indicative of existence of PLC but there is a need to further investigate its existence empirically. The study is designed to investigate existence of the PLC in private schools of Lahore. 


\subsection{Research Questions}

1. Are dimensions of PLC operative in the sample schools as measured by the PLCA-R?

2. How dimensions of the PLC differ in schools by teacher gender?

\section{Methodology}

This quantitative study employed descriptive survey design.

\subsection{Sample}

The private schools located in union council Johar Town of the Iqbal Town made up the population for this study. Lahore is administratively divided into 9 towns and Iqbal town is one of the nine town where a large number of private schools are operating. The researcher conveniently selected five schools of the union council Johar Town, these schools allowed access to the teachers for the current study. The schools' administration did not allow to use the actual names of the schools thus pseudonyms were used by the researcher.

Table 1

Sample Schools

\begin{tabular}{ccc}
\hline Name & No of Students & Characteristics of the School \\
\hline Heaven & 1200 & A well renowned missionary school founded in 1892 \\
Shining Star & 2000 & An English medium private school having a large student body \\
Custodian & 1000 & An Islamic school imparting contemporary education \\
Grammar & 1300 & An English medium school catering needs of students from \\
Hospitality & 5000 & preschool to Levels \\
\end{tabular}

The schools were selected conveniently. The questionnaire was sent to all 800 teachers. Four hundred and eighty questionnaires were received and 430 were having complete responses from participants and used in data analysis. The response rate was $60 \mathrm{~s} \%$. Detail of the sample characteristics were given in the table 2 .

Table 2

Sample

\begin{tabular}{cccc} 
& Sample & & \\
\hline Demographics & & Number & Frequency \\
\hline Gender & Male & 182 & 42.3 \\
Schools & Female & 248 & 57.5 \\
& 1 & 100 & 23.3 \\
& 2 & 70 & 16.3 \\
Age (Years) & 3 & 80 & 18.6 \\
& 4 & 100 & 23.3 \\
& 5 & 80 & 18.6 \\
& $20-25$ & 53 & 12.3 \\
Teaching Experience & $26-30$ & 103 & 24 \\
& $31-35$ & 100 & 23.3 \\
& $36-40$ & 98 & 22.8 \\
& $>40$ & 76 & 17.7 \\
& 1 & 151 & 35.1 \\
Qualification & 2 & 158 & 36.7 \\
& 3 & 75 & 17.4 \\
& 4 & 30 & 7 \\
& 5 & 16 & 3.7 \\
& Professional & 203 & 47.2 \\
& Academic & 227 & 52.8 \\
\hline
\end{tabular}

\subsection{Instrument}

Professional Learning Community Assessment Revised developed and revised by the Olivier, Hipp, \& Huffman (2010) was used to collect data. Permission was obtained from Oliver et al. for the use of the questionnaire for the current research. It comprised of 52 items which are categorized into five sub- 
scales. The instrument was pilot tested to establish its reliability in local context. The details of the subscales and corresponding reliability are given in table 3. Reliability of the composite scale was .951 .

Table 3

Details of sub-scales, number of items and Cronbach alpha coefficient for SPSS

\begin{tabular}{cccc}
\hline Sub-Scales & Items & Reliability \\
\hline 'Shared \& supportive leadership & $1-20$ & .900 \\
Collective learning and application & $21-30$ & .842 & .796 \\
Shared personal practices & $31-37$ & .750 & .759 \\
Supportive conditions (relationships) & $38-42$ & $43-52$ & \\
Supportive conditions (structures) & & \\
\hline
\end{tabular}

\section{Findings}

According to table 4 most of the teachers highly agreed $(M=3.18)$ that decisions in their school are made keeping in view schools' mission and values. Similarly, a very positive agreement is evident among most of the teachers about alignment of policies with vision of the school $(M=3.14)$, "use of data for decision making" $(\mathrm{M}=3.12)$ and scope of initiating change $(\mathrm{M}=3-12)$. If we see on other side of continuum then involvement of staff members appeared at lowest rank $(M=2.83)$, along with distribution of leadership ( $\mathrm{M}=2.91)$ and involvement of staff in decision making $(\mathrm{M}=2.94)$.

Table 4

Shared and supportive leadership dimension of PLC

\begin{tabular}{lll}
\hline Statements & M & SD \\
\hline 1. Alignment of decisions with vision and values of school & 3.18 & 0.67 \\
2. Alignment of program and policies with stated vision & 3.14 & 0.73 \\
3. Use of multiple sources of data by staff & 3.12 & 0.68 \\
4. Support to initiate change & 3.12 & 0.72 \\
5. Head is proactive and provide support & 3.10 & 0.70 \\
6. Innovation is rewarded by principal & 3.10 & 0.71 \\
7. Shared vision is developed collaboratively & 3.10 & 0.68 \\
8. Student learning is of prime importance & 3.09 & 0.71 \\
9. Decisions about teaching and learning are set collaboratively & 3.07 & 0.60 \\
10. Vision is shared to improve learning of students by staff & 3.06 & 0.65 \\
11. Key information are shared with staff & 3.05 & 0.72 \\
12. High expectations are set for students to increase their achievements & 3.03 & 0.78 \\
13. Actions are priorities as per shared vision and available data & 3.03 & 0.85 \\
14. Values are developed collaboratively & 3.00 & 0.67 \\
15. All stakeholders share responsibility to improve learning of students & 2.96 & 0.77 \\
16. Collaborative decision making is evident at all levels in school & 2.95 & 0.79 \\
17. Principal seeks input from teachers to make decisions & 2.94 & 0.75 \\
18. Power and authority is shared democratically by principal & 2.93 & 0.81 \\
19. Leadership is distributed across the school & 2.91 & 0.81 \\
20. Decisions about school issues are taken collaboratively & 2.83 & 0.74 \\
\hline
\end{tabular}

Table 5 indicates perception of 430 teachers about "collective learning and application dimension" of PLC in five different schools of the Lahore.

Table 5

Collective learning and application dimension of PLC

\begin{tabular}{rlll}
\hline Statements & $M$ & $S D$ \\
\hline 1. & Focus of professional development is improvement in teaching and learning & 3.14 & .68 \\
2. & Diverse needs of the learners are taken care jointly by the staff & 3.13 & .65 \\
3. & Programs that enhance learning of the students are implemented & 3.12 & .68 \\
4. & Teaching and learning are improved by collaboratively looking at the work of the students & 3.11 & .68 \\
5. & Dialogue is triggered among staff members to initiate inquiry & 3.10 & .64 \\
\hline
\end{tabular}


6. New knowledge is incorporated collaboratively and implemented

7. Exemplary relationships exist among teachers which aim to improve performance of school

8. Learning flows across all staff members and applied to solve problems

9. Instructional improvement happens after collaboratively evaluating the available data

10. Opportunities are available to initiate dialogue and learn from each other

According to the table 4 the teachers were in very positive agreement that professional development in their schools focus on teaching and learning $(M=3.14)$. All of the five schools taken for the study are well reputed private schools of Lahore and mostly are known because of their quality education. The lowest ranked statements in this dimension included, lack of opportunities for open dialogue in schools $(\mathrm{M}=2.99)$, use of data for assessing effectiveness of their instructional practices $(\mathrm{M}=3.00)$.

Table 6

Shared personal practices dimension of PLC

\begin{tabular}{|c|c|c|}
\hline Statements & $\mathrm{M}$ & SD \\
\hline 1. Opportunities exist for coaching and mentoring & 3.13 & 0.70 \\
\hline Individuals and teams have the opportunity to apply learning & 3.13 & 0.60 \\
\hline Staff members collaboratively review student work & 3.11 & 0.71 \\
\hline 4. Staff members informally share ideas and suggestions & 3.06 & 0.69 \\
\hline Staff members regularly share student work to guide overall school improvement. & 3.01 & 0.68 \\
\hline Staff members provide feedback to peers related to instructional practices. & 2.97 & 0.72 \\
\hline Opportunities exist for staff members to observe peers and offer encouragement. & 2.92 & 0.74 \\
\hline
\end{tabular}

According to table 6 most of the teachers have shown their agreement on availability of coaching and mentoring opportunities in their schools $(M=3.13)$ and that they apply and share consequences of their practices in schools $(M=3.13)$. Besides these the lowest ranked item was the opportunities for peer observation and feedback $(\mathrm{M}=2.92)$.

Table 7

Supportive condition - relationships dimension of PLC

\begin{tabular}{rll}
\hline Statements & M & SD \\
\hline 1. & Relationships among staff members support honest and respectful examination of \\
data to enhance teaching and learning. & 3.17 & 0.73 \\
2. & & \\
& & \\
3. Saring relationships exist among staff and students & 3.15 & 0.72 \\
& & \\
& & 0.71 \\
4. A culture of trust and respect exists for taking risks. & 2.99 & 0.74 \\
5. Outstanding achievement is recognized and celebrated regularly in our school. & 2.98 & 0.86 \\
\hline
\end{tabular}

According to table 7 the teachers rated high the items related to "honest and respectful analysis of data for improvement in teaching and learning" $(\mathrm{M}=3.17)$ and an environment of trust and respect among teachers and students $(\mathrm{M}=3.17)$. Whereas, the teachers in all five schools rated items related to recognition of achievements $(M=2.98)$, and culture for initiation $(M=2.99)$ as low.

Table 8

Supportive conditions - structure dimension of PLC

\begin{tabular}{rrr}
\hline Statements & M & SD \\
\hline $\begin{array}{l}\text { The proximity of grade level and department personnel allows for ease in } \\
\text { collaborating with colleagues. }\end{array}$ & 3.22 \\
2. Communication systems promote a flow of information among staff members. & 3.13 & 0.65 \\
\hline
\end{tabular}



3. The school facility is clean, attractive and inviting.

$\begin{array}{ll}3.13 & 0.66 \\ 3.12 & 0.70\end{array}$
4. Communication systems promote a flow of information across the entire school $3.12 \quad 0.70$ community
5. Time is provided to facilitate collaborative work.
$3.10 \quad 0.77$
6. Data are organized and made available to provide easy access to staff members.
$3.09 \quad 0.71$
7. The school schedule promotes collective learning and shared practice.
$3.07 \quad 0.74$
8. Appropriate technology and instructional materials are available to staff.
3.05
0.73
9. Resource people provide expertise and support for continuous learning.
$3.01 \quad 0.67$
10. Fiscal resources are available for professional development.
$3.00 \quad 0.74$

Most of the items included in this dimension of the PLC in participating schools were rated high by almost all of the teachers. Teachers can approach to their managers $(\mathrm{M}=3.22)$ and the communication is open $(\mathrm{M}=3.13)$. The least rated items included availability of financial resources for professional development of teachers and expert advice for continuous learning $(\mathrm{M}=3.01)$.

In the following section the analysis was conducted to answer research question 2 of the study. Gender and perceptions about PLC

Table 9

Comparison of male \& female teachers scores

\begin{tabular}{lcccccc}
\hline Sub-Scales & \multicolumn{2}{c}{$\begin{array}{c}\text { Male } \\
(\mathrm{n}=182)\end{array}$} & \multicolumn{2}{c}{$\begin{array}{c}\text { Female } \\
(\mathrm{n}=248)\end{array}$} & & \\
\cline { 2 - 5 } & $\mathrm{M}$ & $\mathrm{SD}$ & $\mathrm{M}$ & $\mathrm{SD}$ & & $t$ \\
\hline Shared \& supportive leadership & 60.48 & 9.61 & 60.89 & 7.68 & -.472 & .637 \\
Collective learning \& application & 27.92 & 4.29 & 27.70 & 3.87 & .553 & .581 \\
Shared personal practices & 21.56 & 3.48 & 21.14 & 3.06 & 1.29 & .198 \\
Supportive conditions-Relationships & 15.54 & 2.82 & 15.08 & 2.51 & 1.82 & .069 \\
Supportive conditions-Structure & 30.89 & 4.57 & 30.95 & 4.86 & -.138 & .890 \\
\hline
\end{tabular}

Insignificant difference in perception of male and female on five dimensions of PLC was found. They hold similar views about different dimensions of the PLC, and this may be because the selected schools were all private and established decades back and having well established school processes and leadership.

Table 10

One-way ANOVA for five dimensions of PLC across five schools

\begin{tabular}{|c|c|c|c|c|c|c|}
\hline \multicolumn{2}{|c|}{ Dimensions of PLC } & SS & $\mathrm{df}$ & MS & $\mathrm{F}$ & Sig. \\
\hline \multirow{2}{*}{ SS1 } & Between & 1255.283 & 4 & 313.821 & \multirow{2}{*}{4.434} & \multirow{2}{*}{$.002 *$} \\
\hline & Within & 30077.668 & 425 & 70.771 & & \\
\hline \multirow{2}{*}{$\mathrm{SS} 2$} & Between & 90.601 & 4 & 22.650 & \multirow{2}{*}{1.382} & \multirow{2}{*}{.239} \\
\hline & Within & 6965.596 & 425 & 16.390 & & \\
\hline \multirow{2}{*}{ SS3 } & Between & 38.088 & 4 & 9.522 & \multirow{2}{*}{.902} & \multirow{2}{*}{.463} \\
\hline & Within & 4488.330 & 425 & 10.561 & & \\
\hline \multirow{2}{*}{ SS4 } & Between & 75.119 & 4 & 18.780 & \multirow{2}{*}{2.696} & \multirow{2}{*}{$.030 *$} \\
\hline & Within & 2960.046 & 425 & 6.965 & & \\
\hline \multirow{2}{*}{ SS5 } & Between & 124.734 & 4 & 31.183 & \multirow{2}{*}{1.392} & \multirow{2}{*}{.236} \\
\hline & Within & 9518.310 & 425 & 22.396 & & \\
\hline
\end{tabular}

Table 10 indicated significant differences in perceptions among teachers of five schools regarding "shared and supportive leadership and supportive conditions-structure". The table indicated no significant difference in perception of teachers from five schools regarding dimensions collective learning and application, shared personal practices and supportive conditions-structure. Post-Hoc LSD was conducted to further identify the differences among schools with respect to each dimension. LSD results revealed that in case of dimension 1, shared and supportive leadership, perceptions of teachers from Heaven school are significantly better that Hospitality school $(\mathrm{MD}=3.55, \mathrm{p}=.005)$. It further identified that Custodian school has better perception as compared to Shining star school (MD=-3.93, $\mathrm{p}=.014)$ and school $5(\mathrm{MD}=5.10, \mathrm{p}=.000)$. No significant differences were seen in other pairs. Heaven School is oldest among five and thus having better developed its processes. It has hundreds of schools in Pakistan and abroad as well. Hospitality school is also an International school having more than a dozen 
branches in Pakistan. Recently the school faced challenges at leadership level because of a turmoil in a brother country. Custodian School is recognized because of not only its quality of education but a strong ethical leadership. Shining star School is run by a semi government governing body and Hospitality school has completed about 25 years of its existence and made name because of its success in local examination. LSD results further revealed that in case of dimension 2, supportive conditions (relationships), Heaven school has better conditions which support relationships as compared to Hospitality school (MD=1.14, $\mathrm{p}=.004)$, whereas Custodian school differed significantly with Hospitality school ( $\mathrm{MD}=1.100, \mathrm{p}=.009)$. Heaven School and Custodian school have provided better conditions to teachers which are conducive for development of relationships as compared to other three schools.

\section{Discussion}

In this exploratory investigation, an effective PLC as identified in literature (DuFour, et. al., Oliver, Hipp \& Huffman 2010) was recognized in five private schools of Lahore. All the components of PLC were in an effective state. Collaborative learning and application was particularly influential in this PLC. A key mechanism in the success of PLC is ensuring that school leadership is supportive and participative. Collective understanding of vision and mission and shared learning mechanisms ensure the communication of high expectations to all stakeholders to focus on school improvement. Personal practices should be shared regularly. This study conforms with earlier studies (Meirink, Meijer, Verloop \& Bergen., 2009) that the collaborative learning activities like reflection, observation, action research provide a powerful learning environment which leads to ultimate goal of improving school and student achievement.

\section{Conclusion and implications}

To conclude, the status of school PLC in private schools is excellent and well- established. This study provide insight into perceptions of teachers in this schools that they are highly aware of all the key factors making PLCs effective and all the key stakeholders were in continuous touch with each other to put in collaborative efforts to establish a PLC.

\section{References}

Tam, A. C. F. (2015). Exploring teachers' beliefs about teacher learning in professional learning communities and their influence on collegial activities in two departments. Compare: A Journal of Comparative and International Education, 45(3), 422-444.

Blankstien (2010). Failure is not an option. California: Corwin Press.

Boyer, E. (1995) The basic School: A Community for Learning. Princeton, NJ: The Carnegie Foundation for the Advancement of Teaching.

Brodie, K. (2013). The power of professional learning communities. Education as change, 17(1), 5-18.

Boyd, V. (1992). School context. Bridge or barrier to change? Austin, Texas: Southwest Educational Development Laboratory.

Dana, N.F. and Yendol-Hoppey, D. (2008). The reflective educator's guide to professional development: coaching inquiry-oriented learning communities. Thousand Oaks, CA: Corwin Press.

Darling-Hammond, L. (1996). The quiet revolution: Rethinking teacher development. Educational Leadership, 53(6),4-10.

DuFour, R., \& Eaker, R. (1998). Professional learning communities at work: Best practices for enhancing student achievement. Bloomington, IN: Solution Tree.

DuFour, R. (2007). Professional learning communities: A bandwagon, an idea worth considering, or our best hope for high levels of learning?.Middle School Journal, 39(1), 4-8.

DuFour, R.,(2004). What is PLC? Educational leadership, 61(8), 6-11.

DuFour, R. B., DuFour, R., \& Eaker, R. E. (2006).Professional learning communities at work: Plan book. Bloomington, IN: Solution Tree.

Fullan. M, Hill P., \& Crevola, C. (2006). Break through. Thousand Oaks. CA: Corwin.

Fullan, M. (1997) Broadening the concept of teacher leadership. In S. Caldwell(ed.), Professional 
Development in Learning- centered schools(Oxford, OH: National Staff Development Council),pp.3448.

Fullan, M. and Stieglebauer, S. (1991) The New Meaning of Educational Change,, 2nd Edn (New York: Teachers College Press).

Doolittle, D., Sudeck, M., \& Rattigan, P. (2008) Creating Professional Learning Communities: The Work of Professional Development Schools, Theory Into Practice, 47:4, 303-310, DOI: 10.1080/00405840802329276

Grossman, P., S. Wineburg, and S. Woolworth. (2001). Toward a theory of teacher community. Teachers College Record 103 (6): 942-1012.

Hallinger, P., \& Heck, R. H. (1996). Reassessing the principal's role in school effectiveness: A review of empirical research, 1980-1995. Educational administration quarterly, 32(1), 5- 44.

Hipp, K. K., Huffman, J. B., Pankake, A. M., \& Olivier, D. F. (2008). Sustaining professional learning communities: Case studies. Journal of Educational Change, 9, 173-195.

Hilliard, A.T. (2012). Practices and value of a PLC in higher education. Contemporary Issues in Education Research, 5(2), 71-74.

Hord, S.M. (1997). Professional learning communities: Communities of continuous inquiry and improvement. Austin: Southwest Educational Development Laboratory.

Hord, S. M. and Sommers, W.A. (2008). Leading professional learning communities: voices from research and practice. Thousand Oaks, CA: Corwin Press.

Hord, S. M., Abrego, J., Moller, G., Olivier, D. F., Pankake, A. M., \& Roundtree, L. (2010). Demystifying professional learning communities: School leadership at its best. R\&L Education.

Leithwood, K. (1994). Leadership for school restructuring. Educational administration quarterly, 30(4), 498-518.

Leithwood, K., \& Duke, D. L. (1998). Mapping the conceptual terrain of leadership: A critical point of departure for cross-cultural studies. Peabody Journal of Education, 73(2), 31-50.

Leithwood, K. A., \& Riehl, C. (2003). What we know about successful school leadership. Nottingham: National College for School Leadership.

Lieberman, A.,\& Miller, L.(2011). Learning communities: The starting point for professional learning is in schools and classrooms. Journal of Staff Development, 32(4), 16-20.

Little, J. W. (1990). The persistence of privacy: Autonomy and initiative in teachers' professional relations. Teachers College Record 91 (4): 509-536.

Louis, KS. \& Kruse, S.D. (1995).Professionalism and community: Perspectives on reforming urban schools .Thousand Oaks, California: Corwin Press.

Maloney, C.,\& Konza, D.(2011).A case study of teachers' professional learning: Becoming a community of professional learning or not?. Issues in Educational Research, 21(1), 75- 87.

McLaughlin, M.W. \& Talbert, J.E. (1993). Contexts that matter for teaching and learning. Stanford, California: Center for Research on the Context of Secondary School Teaching, Stanford University.

Midgley, C. \& Wood, S. (1993) Beyond site-management: Empowering teacher to reform schools. Phi Kappan, 75(3),245-252.

Meirink, J. A., Meijer, P. C., Verloop, N., \& Bergen, T. C. (2009). Understanding teacher learning in secondary education: The relations of teacher activities to changed beliefs about

teaching and learning. Teaching and teacher education, 25(1), 89-100.

Napier.R.\& Gershenfeld,M. (2001).Theory and experience. Boston:Houghton Mifflin.

Nelson, T. H. (2009). Teachers' collaborative inquiry and professional growth: Should we be optimistic? Science Education,93(3),548-580.

Olivier, D. F., Hipp, K. K., \& Huffman, J. B. (2010). Assessing and analyzing schools. In K. K. Hipp \& J. B. Huffman (Eds.). Demystifying professional learning communities: School leadership at its Best. Lanham, MD: Rowman \& Littlefield.

Sun-Keung Pang, N., Wang, T., \& Lai-Mei Leung, Z. (2016). Educational reforms and the practices of 
PLC in Hong Kong primary schools. Asia Pacific Journal of Education, 36(2), 231-247.

Pella, S. (2011). A situative perspective on developing writing pedagogy in a teacher PLC. Teacher Education Quarterly, 38(1), 107-125.

Prestine, N.A. (1993). Extending the essential schools metaphor: Principal as enabler. Journal of School Leadership, 3(4), 356-379.

Rosenholtz, S. (1989). Teacher's workplace: The social organization of schools. NewYork: Longman.

Senge, P. (1990). The fifth discipline: The art and practice of the learning organizations. New York: Currency Doubleday.

Sergiovanni T. J.(1994) Building community in schools. San Francisco: Jossy Bass.

Smith, W. F., \& Andrews, R. L. (1989). Instructional leadership: How principals makes a difference. Alexandra, VA: Association for Su- pervision and Curriculum Development.

Snyder, K. J. (1996). Principals Speak Out on Changing School Work Cultures. Journal of Staff Development, 17(1), 14-19.

Tan, Y. S. M., \& Caleon, I. S. (2016). Problem finding in Professional Learning Communities: A learning study approach. Scandinavian Journal of Educational Research, 60(2), 127-146.

Wignall, R. (1992, June). Building a collaborative school culture: A case study of one woman in the principalship. Paper presented at the European Conference on Educational Research, Enschede, The Netherlands.

Wong, J. L. N. 2010. Searching for Good Practice in Teaching: A Comparison of Two Subject- Based Professional Learning Communities in a Secondary School in Shanghai. Compare 40 (5): 623639 